\title{
Development of a High Fiber Content Batter
}

\section{by}

\author{
R.M.A.L.B Ratnayake
}

Thesis submitted to the University of Sri Jayawardanepura for the award of the degree of Master of Science in Food Science and Technology. 


\section{DECLERATION}

The work described in the this thesis was carried out by me under the supervision of Prof Arthur Bamunuaracchi and a report on this have not been submitted in whole or in part of any University or any other institution for another Degree/diploma.

Date:.. RQ0.6...!!!...‥

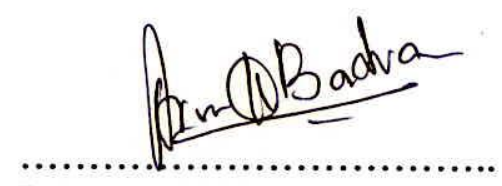

R.M.A.L.B.Ratnayake 
I certify that the above statement made by the candidate is true and this thesis is suitable for submission to the University for the purpose of evaluation.

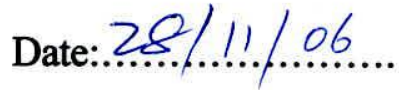

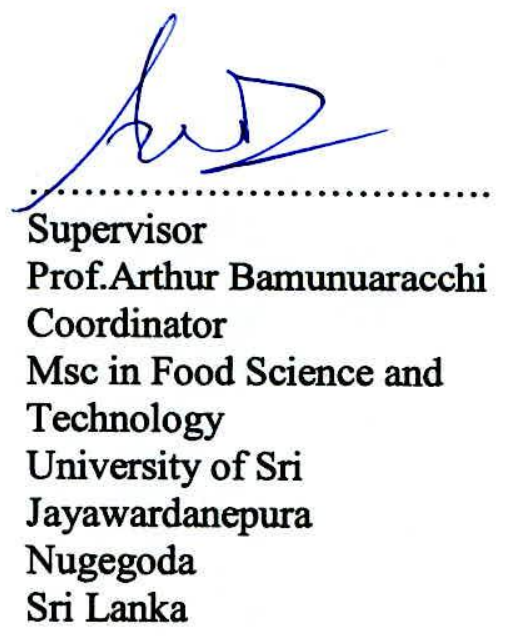




\section{CONTENTS}

\section{PAGE.}

TABLE OF CONTENTS I i

LIST OF TABLES V v

LIST OF FIGURES vi

ACKNOWLEDGEMENTS vii

ABSTRACT viii

1. Introduction 1

2. Literature Review 4

2.1 Production of coated foods 4

2.2 Coated foods in Market place 4

2.3 Formulation of batter systems 5

2.4 Functions of the specific Ingredients 6

2.4.1 Flour 6

2.4.2 Flour Starch $\quad 6$

$\begin{array}{ll}\text { 2..4.3 Flour Protein } & 8\end{array}$

$\begin{array}{ll}2.4 .4 \text { Milk } & 9\end{array}$

$\begin{array}{ll}\text { 2.4.5 Whey } & 9\end{array}$

$\begin{array}{ll}\text { 2.4.6 Soy Flour } & 10\end{array}$

$\begin{array}{ll}2.4 .7 \text { Egg } & 10\end{array}$

$\begin{array}{ll}\text { 2.4.8 Leavening } & 10\end{array}$

$\begin{array}{ll}2.4 .9 \text { Starch } & 11\end{array}$

$\begin{array}{ll}2.4 .10 \text { Salt } & 11\end{array}$

$\begin{array}{ll}\text { 2.4.11 Sugar } & 12\end{array}$

$\begin{array}{ll}2.4 .12 \text { Spices } & 12\end{array}$ 
$\begin{array}{ll}\text { 2.4.14 Colors } & 13\end{array}$

$\begin{array}{ll}2.5 \text { Classification of batters } & 14\end{array}$

2.5.1 Starch based batters $\quad 14$

2.5.2 Flour -based batters $\quad 15$

$\begin{array}{ll}\text { 2.6 Batter characteristics } & 15\end{array}$

2.6.1 Batter viscosity $\ldots 16$

$\begin{array}{ll}2.7 \text { Substrate characteristics } & 16\end{array}$

$\begin{array}{ll}2.8 \text { Corn dog batter mix } & 16\end{array}$

$\begin{array}{ll}2.9 \text { Fibre in diet } & 17\end{array}$

2.9.1 Dietary recommendations 19

$\begin{array}{ll}2.10 \text { Kohila and Radish } & 19\end{array}$

$\begin{array}{ll}2.10 .1 \text { Radish } & 19\end{array}$

$\begin{array}{ll}2.10 .2 \text { Kohila } & 19\end{array}$

$\begin{array}{ll}3 \text {.0 Materials and Methods } & 20\end{array}$

$\begin{array}{ll}\text { 3.1. Material } & 20\end{array}$

$\begin{array}{ll}\text { 3.1.1 Materials } & 20\end{array}$

$\begin{array}{ll}\text { 3.1.2. Equipment } & 20\end{array}$

$\begin{array}{ll}\text { 3.2 Method } & 21\end{array}$

3.2.1 Preparation of Kohila and Radish powder $\quad 21$

3.2.2 Preparation of different proportions of the batter mixture $\quad 21$

3.2.2.1 Preparation of batter mixture by using 21

Kohila powder 
3.2.2.2 Preparation of batter mixture by using

Radish powder

3.2.3 Procedure for making pancake and Chinese rolls

3.2.4 Preparation of pancake and Chinese roll 23

3.2.5 Estimation of Crude fibre, Moisture and ash in the initial 23 powder

3.2.5.1 Determination of crude fibre $\ldots \ldots .24$

$\begin{array}{ll}\text { 3.2.5.1.1 Materials } & 24\end{array}$

3.2.5.1.2 Methods 24

3.2.5.2 Determination of Moisture 25

$\begin{array}{ll}\text { 3.2.5.2.1 Materials } & 25\end{array}$

$\begin{array}{ll}\text { 3.2.5.2.2 Methods } & 25\end{array}$

3.2.5.3 Determination of total ash 26

$\begin{array}{ll}\text { 3.2.5.3.1 Materials } & 26\end{array}$

3.2.5.3.2 Methods $\quad 26$

3.2.6 Estimation of Crude fibre ,Moisture and ash in final 27

pancake

$\begin{array}{ll}\text { 3.2.7 Sensory evaluation } & 27\end{array}$

$\begin{array}{ll}\text { 3.2.7.1 Testing criteria } & 27\end{array}$

$\begin{array}{ll}3.2 .7 .2 \text { Sample serving } & 27\end{array}$

$\begin{array}{ll}\text { 3.2.7.3 Statistical analysis } & 28\end{array}$

$\begin{array}{ll}\text { 3.2.8 Microbiology Analysis } & 28\end{array}$

$\begin{array}{ll}4.0 \text { Results and Discussion } & 29\end{array}$

$\begin{array}{ll}4.1 \text { Chemical analysis } & 29\end{array}$ 
$\begin{array}{ll}4.2 \text { Sensory Evaluation } & 30\end{array}$

$\begin{array}{ll}\text { 4.2.1 Appearance } & 30\end{array}$

$\begin{array}{ll}\text { 4.2.2 Flavor } & 31\end{array}$

$\begin{array}{ll}\text { 4.2.3 Texture } & 31\end{array}$

$\begin{array}{ll}\text { 4.2.4 Color } & 32\end{array}$

4.2.5 Overall acceptability 32

4.3 Microbiology analysis $\ldots \ldots \ldots$

$\begin{array}{ll}5.0 \text { Conclusion } & 35\end{array}$

$\begin{array}{ll}6.0 \text { References } & 36\end{array}$

$\begin{array}{ll}7.0 \text { Appendices } & 37\end{array}$

$\begin{array}{ll}\text { Appendix-1 } & 37\end{array}$ 


\section{LIST OF TABLES}

\section{PAGE}

Table. 1 Different proportions of the mixtures.

Table. 2 Proximate chemical analysis-Initial powder 28

Table. 3 Proximate chemical analysis-pancake 28

Table. 4 Microbiology analysis 


\section{LIST IF FIGURES}

PAGE

Figure.1 Procedure for making pancake and Chinese rolls 22

Figure.2 Mean scores for appearance

Figure.3 Mean scores for flavors

Figure .4 Mean scores for Texture

Figure .5 Mean scores for Color

Figure .6 Mean scores for Overall acceptability 


\section{ACKNWOLEDGEMENTS}

First and foremost I wish to express my sincere gratitude to my project supervisor Prof. Arthur Bamunuaracchi, coordinator, Msc. in Food Science and Technology program, University of Sri Jayawardanepura, with out whose guidance this work would have not been possible. I am deeply grateful to him for the invaluable guidance and encouragement given to me through out this project.

My sincere thanks are also due to Dr.K.K.D.S.Ranaweera,Head Department of Food Science and Technology, University of Sri Jayawardanepura, for his advice and valuable guidance.

I wish to extend my gratitude to the Chief Executive Officer Keells Food Products Limited, Mr.Asitha Samaraweera for given me the permission to carry out the project in Keells Food Product Ltd. I also would like to thank all the staff members of the Keells Food Products Ltd who assisted me and helped me for succeeding at the project work.

I also wish to thanks Mr.Rohitha Hewadikaram, and Mr.Mahesh of Pragathi Foods for the help given me during initial sample preparation.

I would like to acknowledge help given by the Director Industrial Technology Institute Colombo for giving me permission to obtain library facilities.

My sincere thanks are also due to my loving wife Kumari for the invaluable assistance given me to prepare this thesis in a short time.

Last but not least I wish to thank Mr.Rupasinghe and all other members of Nonacademic staff of the department of Food Science and Technology and all my friends in Msc course who gave their valuable assistance. 


\title{
Development of a High Fiber Content Batter
}

by

\author{
R.M.A.L.B Ratnayake
}

\begin{abstract}
Batter and breaded food products have long been popular consumer food items. Coating sea foods, poultry, red meat and vegetable products with a batter and/ or breading is common practice in modern food business. Fish fingers, Chinese rolls, fish cake, burgers, cutlets are the staple battered and breaded food items while battered poultry, Oyters, Shrimps, Scallops, cater to luxury markets and widely used in restaurant trade. The development of basic recipes for the batters has been done time to time and the technology has been developed to get the desired batter characteristics. The nutritional qualities in batters have also play an important role
\end{abstract}

The objective of this study was to develop a high fibre contained batter that can be used in Chinese rolls production by using easily available ingredients. The Kohila (Lasia spinosa) powder and Radish ( were used for the recipe formulation. The existing recipe which is used in pancake production for Chinese rolls has been modified by adding different proportions of the Kohila (Lasia spinosa) and Radish (Raphanus sativus) powder. Four recipes were developed for each variety .Because of the high 
water absorption rate of Kohila and Radish dehydrated powder was used during recipe formulation.

The crude fibre percentages of the pancake with new recipes and the existing recipe were determined. Chinese rolls prepared from the pancakes of the above recipes were subjected to sensory evaluation with the control to asses organoleptic properties.

The crude fibre percentages of the pancake which were made from Kohila and Radish were $10-12 \%$ high with comparing to normal batter. The overall acceptability of sample made of $50 \%$ radish was significantly lower than that of the control. There was no significant difference between the other batter formulations and the control for overall acceptability. 


\section{Introduction}

Batter and breaded food products have long been popular consumer food items. Coating sea foods, poultry, red meat and vegetable products with a batter and/ or breading before cooking is a common practice in home makers, food processors and commercial food establishment modern food items. Recently the relative importance of coating has shifted from the home maker to use in restaurant and fast food outlets.

The commercial production of battered and breaded food items has increased by quantum loops.

Batter can be defined as a thick beaten liquid mixture as of flour, milk and eggs. But if correctly defined batter is a liquid mixture comprised of water, flour, starch and seasonings in food products are dipped prior to cooking.

A coating will be referred to as the batter or the breading adhering to a food product after cooking.

The market for coated food is actually market for various battered and breaded flesh and vegetable protein products intended for both retail and food service distribution.

An important consideration in the marketing and development of food products is, and will continue to be, taste. There is no better way to enhance flavor and differentiate foods than with coatings.

Viscosity, solids suspension, set-up character, leavening stability, browning rate, and flavor are the important batter selection characteristics. Batter viscosity may determine the success of a batter-coated food product more than any other 
characteristic. Batter viscosity influences the quality and quantity pickup, the potential for voids, the handling ease, breading pick up and the final coating texture. It is it self affected by batter temperature, ingredient composition and solids -water ratio.

The set up character of batters should be evaluated during product development. The batter should be formulated to set quickly if it will be subjected to a prefer. step, where as more slowly setting batter may be used continuous fry operations. The set up character is determined by the flour proteins and starches. Browning rate and flavor considerations form batters are similar to those for breadings.

The effective use of flavorings and seasonings in batter and breading system is more complex than many processes than many processors and food scientists may realize.

The food technologists can draw from a long "shopping list" of ingredients to yield a batter having the required properties. This creative challenge has made batters and breading an ideal area for nurturing new approaches and technologies. The typical formulas can be broken down in to critical and optional ingredients. By altering the optional ingredients can change the batter recipe to give what ever required nutritive characters

Recently, the relative importance of coating has shifted from the homemaker to use and fast food out lets 
Fish fingers, Chinese rolls, fish cake, burgers, cutlets are the staple breaded food items while battered poultry, Oysters, Shrimps ,Scallops , cater to luxury market and widely restaurant trade

As batter technology evolves from art to science, the general role of ingredients come in into focus.

\section{Aims of the project}

Develop a high fibre contained batter that can be used in Chinese rolls production by using easily available ingredients. 